\title{
Exploring Community Tourism in China: The Case of Nanshan Cultural Tourism Zone
}

\author{
Yiping Li \\ Department of Geography, The University of Hong Kong, Pokfulam \\ Road, Hong Kong, China
}

\begin{abstract}
As a sustainable development approach, community tourism can be implemented in a modernized civil society when individuals confront the opportunities and responsibilities of citizenship. China seems to present a series of problems to community tourism. It is in the midst of 'modernising' its norms and values, but has no civil society to counterbalance the power of the state. It enjoys the benefits of a growing economy, but is far from being regulated by the invisible hand of the market. There is intense social opposition, but there are no social movements that might lead towards building a democratic system crucial to implementing community tourism. This paper presents a case study of Nanshan Cultural Tourism Zone in Sanya, Hainan Province, China, in order to explore the applicability of community tourism. The findings indicate that tremendous barriers exist to such a democratic approach in the development of the Zone despite glimmers of hope. The paper concludes that various preconditions must be established for implementing community tourism in the specific situation of the Zone. The paper also contributes to the much needed discussion of community tourism in developing countries.
\end{abstract}

Keywords: Buddhism, China, community tourism, Hainan, Nanshan, Sanya

\section{Introduction}

The concept of community tourism has been developed and refined in the context of developed countries in search of sustainable approaches to tourism development. However, the applicability of such a concept to developing countries seems not to have been considered in detail (Tosun, 2000). Although scholars have explored community tourism issues in China (Hatton, 1999) and other developing countries (Mitchell, 2001; Timothy, 1999), they have mainly focused on community involvement in the economic benefits of tourism and not yet covered the complexity of applying the concept. There remains, therefore, a much needed and important discussion on the implementation of community tourism in developing countries. This paper contributes to this discussion by examining the prospects for, and the barriers to, community tourism in China, with a specific case analysis of Nanshan Cultural Tourism Zone (NCTZ) in Sanya, Hainan Province. The purpose of the paper is threefold: (1) to contribute to the discussion on the practicability of community tourism in developing countries; (2) to identify preconditions for operationalising this approach in the specific situation of NCTZ and; (3) to recommend future directions for research on community tourism in China. 


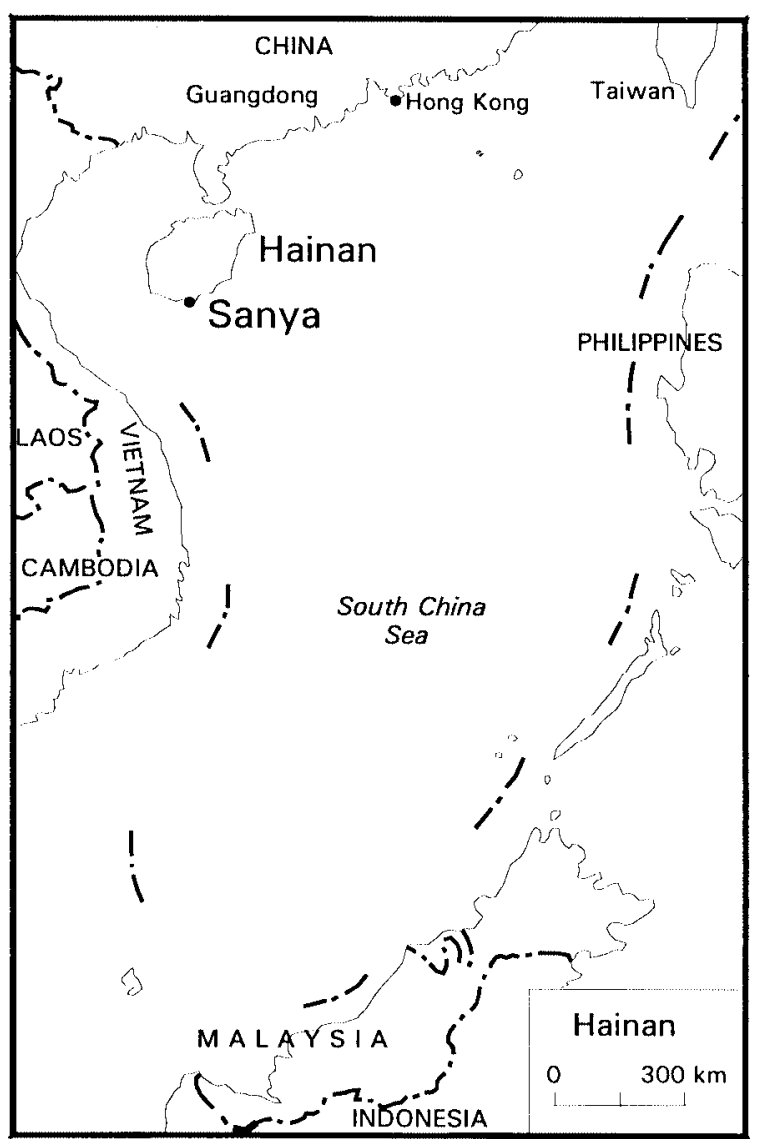

Figure 1 Location map of Sanya, Hainan Province, China

Starting with the background information about the development of NCTZ, the paper first provides a conceptual framework against which the case study is evaluated, and a clarification of the study method. It then examines the prospects for, and the barriers to, implementing community tourism in NCTZ. In conclusion, attention is drawn to the identification of some specific preconditions necessary for operationalising community tourism in NCTZ and to recommendations for future research on community tourism in China.

\section{Background}

Hainan Island, China's only tropical province, located by the South China Sea (Figure 1). It has a land area of $34,000 \mathrm{~km}^{2}$ and a population about 7 million (China National Tourism Administration, 2001a). In 1988, the Chinese Central Government designated Hainan as China's largest Special Economic Zone (SEZ), which accelerated its economic growth, especially tourism. Within a decade its south coast city Sanya was transformed from a remote small town into 
Table 1 Hainan tourism development statistics

\begin{tabular}{||l|l|l|l|l|l|l|l||}
\hline \hline & $\mathbf{1 9 9 5}$ & $\mathbf{1 9 9 6}$ & $\mathbf{1 9 9 7}$ & $\mathbf{1 9 9 8}$ & $\mathbf{1 9 9 9}$ & $\mathbf{2 0 0 0}$ & $\mathbf{2 0 0 1}$ \\
\hline Tourist arrival (10,000) & 361 & 485.8 & 791 & 856 & 929.3 & 1007.6 & 1124.8 \\
\hline Tourist income (billion RMB ${ }^{*}$ ) & 52.4 & 57.23 & 61.67 & 66.96 & 72.46 & 78.56 & 87.89 \\
\hline Annual tourist arrival growth (\%) & 24.7 & 34.6 & 62.8 & 8.2 & 8.5 & 8.5 & 11.6 \\
\hline Annual tourist income growth (\%) & 9.9 & 9.2 & 7.8 & 8.6 & 8.2 & 8.4 & 11.8 \\
\hline Tourist income of GDP (\%) & 16.28 & 14.63 & 15.04 & 15.26 & 15.19 & 15.20 & N/A \\
\hline
\end{tabular}

* $1 \mathrm{RMB}=0.12$ US dollars

Source: Based on Hainan Tourism Bureau (1995-2001) statistics

Table 2 NCTZ's anticipated and actual tourist arrivals (in $=10,000 \mathrm{~s}$ )

\begin{tabular}{|l|c|c|c|c||}
\hline Year & $\mathbf{1 9 9 8}$ & $\mathbf{1 9 9 9}$ & $\mathbf{2 0 0 0}$ & $\mathbf{2 0 0 1}$ \\
\hline Anticipated arrivals & 175.68 & 188.31 & 201.53 & 214.85 \\
\hline Actual arrivals & 11.6 & 77.87 & 129 & 163.79 \\
\hline Difference (\%) & 1414.5 & 141.8 & 56.2 & 31.2 \\
\hline
\end{tabular}

Source: Based on Sanya Tourism Bureau (1998-2001) statistics and the Zone's feasibility report

a modern tropical resort (Table 1). Nanshan (South Mountain), $40 \mathrm{~km}$ to the west of Sanya, has been deemed to be a 'blessed land' in the Buddhist tradition that the benevolent Guanyin (Goddess of Mercy) vowed 12 oaths to save all living things (Sanya Nanshan Industry and Development, 2003). To dwell permanently at the South China Sea near Nanshan was her third oath. Master Jianzhen, the renowned monk in the Tang Dynasty (AD 618-907), tried in vain five times to sail eastwards to Japan to spread Buddhism. On the fifth sailing he drifted to Nanshan. He stayed to preach Buddhism for a year, and eventually succeeded in reaching Japan. These historic tales provide the background for NCTZ's major themes of 'Blessed Land of Longevity' and 'Buddhist Culture'.

Currently under construction, NCTZ started operating the two completed sites - Nanshan Temple and Buddhist Cultural Park - in 1998, but has encountered a series of problems ever since. Firstly, unrealistic market anticipation (Table 2) led to overexpanding the project from 34.7 to 50 and eventually $60 \mathrm{~km}^{2}$ with a capital investment of RMB 70 billion ( $1 \mathrm{RMB}=0.12$ US Dollars). Items which had neither market appeal nor cultural relevance were accumulated, such as an orphanage, a senior nursery house, a kindergarten, and commercial real estate, laying financial pressure on the developer. Secondly, the developer did not realise that temples and other religious sites should be owned and managed by religious groups according to China's religious law (China National State Council, 1981). The developer assumed the Buddhist community would be grateful for the investment in building Nanshan Temple and Buddhist Cultural Park; he took it for granted that the Buddhist community would let the developer run the sites. Once NCTZ started to operate the Buddhist community claimed the ownership of Nanshan Temple and Buddhist Cultural Park - the only two sites 
open to the public so far. Tensions thus emerged between the developer and the Buddhist community. Thirdly, the developer's faulty analysis of the environment led to imports of foreign trees and lawns to Nanshan where sources of irrigation are scarce. Consequently, NCTZ had to hire more than 100 workers daily to look after the man-made ecological environment, adding to the financial pressure. Fourthly, the representations of Buddhist culture that concentrated on tourism were rather superficial, through architectural arrangements such as Nanshan Temple and the giant statue of Guanyin. Irrelevant Western-style villas, resort hotels and even a golf course were built close to those sacred Buddhist sites.

These problems, if unsolved, will hinder NCTZ's further development given that three other planned sites are to be completed. The researcher believes that the problems are consequences of a lack of community participation in the tourism development process, common in China where the public administration of tourism is centralised and an elite domination of business is taken for granted (Swain, 1995; Xia, 1999). However, after China's entry to the World Trade Organisation the country is more willing to accept new development concepts (Yu et al., 2003). This study, therefore, explores the applicability of community tourism in NCTZ for its sustainable development.

\section{Conceptual Framework and Study Method}

Much of the study of community tourism originated from research into tourism's social and economic impacts with the goal of minimising the negative impacts by developing sustainable tourism. Brunt and Courtney (1999) suggested that the attitudes of community residents towards tourism impacts should be important planning and policy considerations for sustainable operation of tourism projects. Researchers showed that as tourism increased in an area, residents' attitudes towards tourism moved through four stages from euphoria, through apathy and annoyance to antagonism (Doxey, 1975); the people who had enjoyed or suffered the main impacts of tourism were those who were living in tourist destination communities (Butler, 1980; Keller, 1987; Smith, 1989). It was argued that the communities should participate in planning decisions regarding tourism development in order to better handle the impacts. In this context, Murphy (1985) held that a destination community should be an important component of the tourism product and that the industry should use the community as a resource, market it as part of the product, and in the process affect the lives of everyone. Therefore, community participation in the tourism development process was necessary to maximise socioeconomic benefits of tourism for the community (Inskeep, 1991), and community involvement in establishing desirable conditions was perhaps the single most important element of growth management in tourist destinations (Williams \& Gill, 1994). A community-based approach to tourism development should be a prerequisite to sustainable development (Ryan \& Montgomery, 1994; Simmons, 1994; Woodley, 1993). Planners should attempt to facilitate sustainable tourism through the reconstruction of social and political institutions (Atkinson, 1991; Stonich, 1998). They should help create sustainable communities resilient enough to survive in a highly volatile 
international environment, rather than 'sustaining' tourism or specific aspects of tourism development (Potts \& Harrill, 1998).

In summary, community tourism is defined as a sustainable approach to developing tourism in such a way 'that intended beneficiaries are encouraged ... to participate in their own development through mobilising their own resources, defining their own needs, and making their own decisions about how to meet them' (Stone, 1989: 207). The ways of participation may vary, but generally include joining in the process of self-governance, responding to authoritative decisions that impact on one's life, and working cooperatively with others on issues of mutual concern (Til, 1984). Although community participation is strongly supported by many, there are in fact four prerequisites for such participation; namely, legal rights and opportunities to participate; access to information; provision of enough resources for people or groups to get involved; and genuinely public, that is, broad instead of selective, involvement from the concerned communities (Pearce et al., 1996). The ultimate goal of community tourism is to empower the destination community at four levels (Scheyvens, 1999). Economic empowerment should ensure lasting economic gains for a destination community. Psychological empowerment should enhance the selfesteem of community members by recognition of the uniqueness and value of the culture, natural resources and traditional knowledge of the community. Social empowerment aims to maintain the community's equilibrium; that is to say, community cohesion is improved as individuals and families work together to build a successful tourism venture. Political empowerment should regard the community's voices and concerns as guides for tourism projects from the feasibility stage through to implementation.

The above literature review provides a conceptual framework that community tourism is a form of voluntary action by which individuals confront opportunities and responsibilities of citizenship (Askew, 1989). It has an ultimate goal to empower the destination community at the economic, psychological, social and political levels so as to achieve sustainable development. Against this conceptual framework, two testable hypotheses were formed for the study. The first was 'individuals work cooperatively with relevant stakeholder groups to deal with issues of mutual concerns', which were tested in terms of the mechanisms in the Chinese society and the willingness of the powerful stakeholders - the local government and the entrepreneurs - to encourage the cooperation. The second was 'individuals confront opportunities and responsibilities of citizenship by responding to authoritative decisions that impact on community life', which were tested in terms of the community's awareness of the opportunities and responsibilities as well as the capacity for participation in the development of NCTZ. The study contributing to this paper was mainly, but not exclusively, qualitative. The researcher has immersed himself in empirical work since October 2000. A number of in-depth interviews were conducted with representatives of the provincial and the city tourism bureaux, the developer and tourism companies, as well as with community residents (Table 3). Other data included participant observation and non-participant observation, reviews of official documents, statistics, printed tourism promotional and marketing materials. The researcher's exposure to the Buddhist community was limited. Despite the historic tales about Guanyin and Master Jianzhen, Nanshan is not a traditional 
Table 3 List of interviewees involved in the in-depth interviews

\begin{tabular}{|c|c|c|}
\hline No & Positions held & Representing \\
\hline 1 & Director of Planning Department, Provincial Tourism Bureau & \multirow[t]{7}{*}{ Government } \\
\hline 2 & Vice Director, Sanya City Tourism Bureau & \\
\hline 3 & Official, Information Centre, Sanya City Tourism Bureau & \\
\hline 4 & Official, Information Centre, Sanya City Tourism Bureau & \\
\hline 5 & Official, Sanya City Bureau of Ethnic and Religious Matters & \\
\hline 6 & Vice Executive Manager, NCTZ* & \\
\hline 7 & Director of Human Resources Office, NCTZ* & \\
\hline 8 & Professor, Tourism College, Hainan University & \multirow[t]{3}{*}{ Academics } \\
\hline 9 & Lecturer, Tourism College, Hainan University & \\
\hline 10 & Professor, Social Science Research Centre, Hainan University & \\
\hline 11 & Director, Sayan Nanshan Industry \& Development Ltd (SNIDL) & \multirow[t]{10}{*}{ Industry } \\
\hline 12 & Executive General Manager, SNIDL & \\
\hline 13 & Head, Human Resource Office, SNIDL & \\
\hline 14 & Chief Executive Officer, SNIDL & \\
\hline 15 & Planner, Planning Department, SNIDL & \\
\hline 16 & General Manager Assistant, SNIDL & \\
\hline 17 & Vice General Manager, Nanshan Buddhist Cultural Park & \\
\hline 18 & System Manager, Nanshan Buddhist Cultural Park & \\
\hline 19 & Vice General Manager, Sanya Pearl Garden Hotel & \\
\hline 20 & Resident Manager, Gloria Resort Sanya & \\
\hline 21 & Village Chief, Duck Pond Village, Nanshan & \multirow[t]{13}{*}{ Community } \\
\hline 22 & Village Police Officer, Duck Pond Village, Nanshan & \\
\hline 23 & Villager, Duck Pond Village, Nanshan & \\
\hline 24 & Villager, Duck Pond Village, Nanshan & \\
\hline 25 & Villager, Duck Pond Village, Nanshan & \\
\hline 26 & Villager, Duck Pond Village, Nanshan & \\
\hline 27 & Buddhist, Chief Executive Officer, Nanshan Temple Foundation & \\
\hline 28 & Monk, Nanshan Temple & \\
\hline 29 & Monk, Nanshan Temple & \\
\hline 30 & Monk, Nanshan Temple & \\
\hline 31 & Monk, Nanshan Temple & \\
\hline 32 & Buddhist, Waitress, Nanshan Temple Vegetarian Restaurant & \\
\hline 33 & Buddhist, Shop Assistant, Nanshan Temple Souvenir Store & \\
\hline
\end{tabular}

* The Chinese central state designated the Nanshan area as a zone for developing cultural tourism, so NCTZ is a government institution. 
Buddhist site, as revealed by the residents interviewed in Nanshan. Nanshan Temple was actually created after the Buddhist Cultural Park had been built in 1998 and the monks were only invited to come afterwards. Therefore, the researcher considered that as the monks had not been long-time residents of Nanshan, NCTZ was not an authentic Buddhist site.

\section{Research Findings}

The researcher believes NCTZ should move towards the community tourism development mode in order to achieve sustainability. The developer must first ease the tensions with the Buddhist community. The developer should also incorporate the knowledge of the local communities in planning the World of South China Sea and the World of Happiness and Longevity, the two theme sites to be developed based on the local culture and tradition (Sanya Nanshan Industry and Development, 2003). In addition, social development and ecological sustainability should be the developer's top concerns if NCTZ is to be a project socially responsible, economically sound, and environmentally friendly (Urban International-New York, 1997). By testing the two hypotheses stated earlier, however, the researcher only found glimmers of hope for applying community tourism, while tremendous barriers exist, particularly regarding the empowerment of the local community at the economic, psychological, social and political levels.

\section{Prospects}

The prospects for applying community tourism in NCTZ can be viewed in both theoretical and practical terms. China's tourism industry effectively started in 1978 and the Chinese understanding of tourism-community relationship began to develop afterwards (Zhang, 1995). From 1978 to the early 1990s, rapid tourism growth brought the country problems such as erosion of culture and tradition, inflation of consumer prices, conflicts between tourists and the residents, as well as an increase in crime (Gormsen, 1995; Li, 2002; Liu, 1992). Some Chinese tourism researchers called for strategies to tackle these problems ( $\mathrm{Li} \&$ Wang, 1988; Lin \& Tao, 1986). Zhang (1998) introduced the concept of sustainable tourism by translating Agenda 21 for the Travel \& Tourism Industry: Towards Environmentally Sustainable Development (World Travel \& Tourism Council et al., 1995) into Chinese. The Chinese realised tourism growth could not be sustained by overexploiting the resources and damaging the environment. The sustainable growth of tourism could not be achieved without the support from the community of the destination (Wu, 2000). Chinese tourism researchers began to study the dynamic relationship between tourism and the local community. They noted tourism should be developed from the various interests of the local community, thereby proposing concepts such as 'additional social costs of tourism' (Cai et al., 2000) and 'community development of destinations' (Tang, 1998). Around 2000, the Chinese scholars' understanding of the tourism-community relationship was transformed. Z.P. Liu (1999) pointed out that a crucial issue in tourism planning was to guarantee local community the rights of defining their own needs and making their own decisions in the planning process. This guarantee would help determine that social and cultural changes associated with tourism devel- 
opment were acceptable. Community involvement appeared in China's tourism development agenda: developers should understand the general interests of the community and those interests must be appropriately considered in the planning process (W.H. Liu, 2000). Through interaction with the community, planners should help the community residents appreciate both the positive and the negative impacts of tourism (M. Liu, 2001).

The Chinese tourism researchers mentioned above understood the tourismcommunity relationship mainly from the developers' point of view. They attempted to prove, in theory, that tourism needed community support and, therefore, developers should seek the cooperation of the community to accomplish projects. As Liu (1999: 29) held, 'when the local residents realise they can exercise influence, they tend to support tourism development'. This understanding of the tourism-community relationship is rather different from the contemporary Western concept of community tourism, which, ultimately, is to sustain the community in the process of tourism development (Potts \& Harrill, 1998; Scheyvens, 1999). However, their studies led to a common view among the Chinese tourism researchers that community support is important for developing tourism. This provides the theoretical prospect of applying community tourism in NCTZ.

In practice the various stakeholder groups involved reflect the attitudes towards community participation of the different interests they represent (Potts \& Harrill, 1998; Tosun, 2000). In NCTZ, the developer's attitude changed from past neglect of the local residents to recent attempts to establish a good relationship with the local community. The developer, Sanya Nanshan Industry and Development Limited (SNIDL), was formed in 1995 when the project was started. The director of SNIDL admitted that the developer did not pay attention to tourism-community relationship until the Master Plan was completed in 1997. As the first phase of the project did not require relocating any local villagers because of changing land use, issues over land compensation did not emerge immediately. Represented by Sanya Municipal Tourism Development Corporation, Sanya city government possesses a $40 \%$ holding in SNIDL. The developer, therefore, would let the government handle affairs with the local community. Essentially the developer did not think the project had anything to do with the local community, assuming the local people would be in favour because tourism growth in China brought economic benefits to poor, remote provinces such as Hainan throughout the 1980s to early 1990s. After NCTZ was partially opened to the public, the developer's attitude changed due to the local residents' attempts to gain rights over the development. According to the assistant general manager of SNIDL and some of the villagers interviewed, the developer had promised, at the planning stage of NCTZ, to create jobs for the residents of nearby villages, help build schools for the local children, and compensate with cash those whose land was expropriated. The promises helped gain the villagers' support but the developer failed to keep them as soon as NCTZ started to operate and generate revenue. Some villagers gathered to negotiate with the developer, and the excitement generated led to violence and a few villagers were taken to jail. Finally, the developer had to make the employment arrangements and pay the compensation. This incident taught the developer a lesson that a good relationship with the local people was essential for the smooth operation of NCTZ. 
In business practice the developer further realised the importance of local support. As the Vice Director of Sanya City Tourism Bureau revealed, the developer had to dissuade the villagers from cutting the trees in the mountains, building houses close to the Zone, and selling souvenirs along the nearby streets in order to keep a ' good environmental image'. He admitted that even the major themes about Buddhism and the Blessed Land of Longevity could not grow out of nothing but must take roots in the land of Nanshan and the lives of the villagers. The chief executive officer of SNIDL told the researcher that during Nanshan Longevity Festival 2000 the developer invited the villagers to participate in the 'Longevity Award' competition. Twelve seniors over 90 years old were identified by the villagers for the competition. According to the respondents working in the tourism and hospitality services, this activity was effective for establishing NCTZ's brand theme of the Blessed Land of Longevity. Apparently the developer had realised the importance of keeping a good relationship with the villagers for operating the Zone. This indicates hopes for practical prospects for applying community tourism in NCTZ. However, the developer's current understanding of tourism-community relationship remains only at the level of keeping good relationship with the villagers: it does not include considering community participation in tourism planning and product development.

In China, the state owns the land and is able to designate anywhere for development (People's Republic of China, 1998). Consequently, communities can only passively allow developers to use their land for any projects that are statesupported such as the project of NCTZ. Developing NCTZ needed to expropriate the land of Duck Pond Village, a traditional agricultural village in Nanshan. The developer offered about 50 jobs to the villagers and compensated every household with cash. However, what the villagers had sacrificed was not only the land but also a livelihood to which they had been attached for generations. A lecturer of the Tourism College, Hainan University, had been observing the change of the village from the beginning of NCTZ. He revealed to the researcher that in five years the village lost half of its cultivated land for the development but the population increased from 680 to 730 people, a great challenge to those who were traditionally agriculture peasants. Consequently, some villagers abandoned their village homes in order to survive elsewhere. The worst effects were the social impacts. According to the interviewed villagers, the land compensation fee paid to each household ranged from RMB 100,000 to RMB 300,000. This was a large sum of cash for the families of the village where average annual household income had never reached RMB 3000. Some villagers went out of their minds with such a windfall, building expensive houses and buying motorcycles. Some even became drug addicts. During the in-depth interviews, a number of villagers expressed their worries about the social impacts, hoping the developer and the Government would help them solve the problems. However, the researcher found tremendous barriers exist to the community's participation in the development of NCTZ.

\section{Barriers}

The barriers can be categorised as political-structural, business-operational and sociocultural. Together, they have created obstacles to empowering the community at the economic, psychological, social and political levels crucial to 
the residents' confronting opportunities and responsibilities of citizenship (Askew, 1989; Scheyvens, 1999). The political-structural barrier manifested itself in NCTZ mainly as the powerful control of the state. In China, the state reach is wide-ranging and touches every economic sector (Swain, 1989, 1990, 1993, 1995; Xia, 1999). Its manipulation of development is a great obstacle to applying community tourism. In NCTZ, the state, represented by the local government as Sanya City Tourism Development Corporation, possesses a $40 \%$ share of SNIDL. As the owner of the land, the local government can designate anywhere for development, with compensation to those whose land is to be expropriated (People's Republic of China, 1998). According to a planner for SNIDL and the villagers interviewed, in NCTZ matters regarding land expropriation and the related compensation were negotiated only between the developer (SNIDL) and the landowner (Sanya City Government). The local villagers were completely excluded from the process. As shareholder of the development company, Sanya City Government should have shared part of the compensation charge. But the negotiations between Sanya City Government and the developer were concluded in a deal that the developer would pay the Government's share while the Government calculated the total and then distributed it to the villagers. Sanya City Government, therefore, could not be expected to protect the villagers' interests seriously, a fact pointed out by a professor from the Tourism College at Hainan University. In the development process, it was not rare to see the Government stand by the developer's side in order to attract more investment capital. Such government manipulation of tourism development encouraged corruption among local officials. Close to the end of 2001, the former director and president of SNIDL stepped down because of a corruption scandal. He was, however, only a scapegoat for some more powerful officials behind the scenes who had connections with the central state in Beijing. Some interviewees who worked in NCTZ alleged to the researcher that the removal of the director and president of SNIDL was necessary in order to close the corruption investigation, otherwise some higher state officials would lose face. Under such circumstances, the development process of NCTZ could not be community driven to allow the local residents to exercise influence. The state's manipulation of tourism development usually made little information available to the local residents regarding how a development might impact on their lives. If the people concerned have no rights to define their own needs and make their own decisions regarding how tourism development should affect their lives, it will be impossible to establish a dynamic tourism-community relationship (Potts \& Harrill, 1998) leading to political empowerment of the community (Scheyvens, 1999).

The business-operational barriers were manifested largely as the developer's unwillingness to let the villagers and the Buddhist community participate in the tourism development process. China has experienced a 'capital hunger' for decades due to the centrally planned economy (Xia, 1999). The current marketoriented reform of the national economy intends, among other goals, to diversify the sources of development capital. In order to attract investment, both the national and the local states adopted policies favourable to developers, which would encourage their feeling of superiority to the local people. For instance, developing NCTZ was in line with the state's new religious policy of preaching 
the so-called 'people's Buddhism' for China's economic reform, described by the Planning Director of Hainan Provincial Tourism Bureau. The policy is to root the spiritual dimension in human interests and happiness (Xia, 2001). When interviewed, quite a few managerial staff of NCTZ assumed the Buddhist community should be grateful for the company's investment in building Nanshan Temple and Buddhist Cultural Park. Some even despised the local villagers as 'moneydriven primitives who knew nothing but money', and the monks as 'ignorant of the business rules required for managing NCTZ'. They considered the villagers and the monks unqualified to participate in planning the development of NCTZ because they were either 'uneducated and rustic' or 'simple-minded and dumb'. They also assumed problems with the local community were easy to handle by 'paying the villagers some compensation money'. In addition, the developer needed to see quick returns from the investment, but community participation would require considerable time, money and skills to organise and sustain participation (Tosun, 2000). When asked about the concept of community tourism, most of the managerial staff would either answer, 'I don't know about that sort of thing,' or 'it is too difficult and complicated to carry out in practice'. This lack of relevant expertise and knowledge might have caused the developers to be reluctant to accept community tourism. However, a more complex issue for applying community tourism is, obviously, that implementing community tourism would mean negotiating mutual interests between the developer and the community. This could not only raise the expectations of the villagers and the monks for the developer to meet but also politically empower the community to question if the Government was seriously protecting their interests. Such a challenge to the foundation of China's large and entrenched bureaucracy (Xia, 1999; Yu et al., 2003; Zhang et al., 1995) could be politically risky, and would require relatively more bureaucratic formalities, demanding more money, organisational skills, time and effort; and disappointing the developer who expected a quick return from his investment (Tosun, 2000).

The sociocultural barriers were manifested, more or less, the villagers' limited capacity and unawareness of tourism impacts. The researcher observed that Nanshan had been a remote area of Sanya. Its economy was undeveloped and the majority of the villagers were very poor. Meeting basic and deeply felt needs had long been their daily fight for survival. Hence, participation in the development process of NCTZ, which demanded time and energy, would be a luxury for them to afford. Besides, the majority of the villagers were illiterate or semi-illiterate ethnic Li people who could hardly speak or read mandarin (official Chinese). They had been excluded from handling socioeconomic and political issues by the majority Han Chinese for centuries, so were not able to develop cultural and economic capacity to handle such matters as tourism development. When interviewed, the villagers generally showed apathy towards participation in the development of NCTZ. They would consider tourism a matter between the 'lao ban men' (the bosses of the company) and the government officials, having little to do with themselves. The chief of the Duck Pond Village told the researcher that he had initiated contacts with SNIDL in order to get involved in the development of NCTZ in the interests of the villagers. However, the villagers misinterpreted his motive as being selfish in order to get more compensation money. He blamed the villagers' low level of interest in participation on this 'peasant livelihood and 
ideology'. China's long history of feudal society has produced a 'natural economy' conceptualised as peasant production for home consumption by the unity of farming and handicraft industry in peasant households (Zhang, 1957). In contemporary Chinese language, terms such as 'peasant livelihood' and 'peasant ideology' have a negative connotation, implying the rural people's lack of vision and attachment to a singularly tenacious form of production, resistant to the separating out of industry from farming into town workshops and hence to capitalist development (Huang, 1991). Therefore, the economic, psychological and social empowerment of the community would be crucially important for the villagers to participate in the development of NCTZ. But neither the local government nor the developer had any plans to bring long-lasting economic gains to the local residents, except paying them the once and for all land compensation fee, as the researcher had observed from the interviews with the villagers, the government officials, and the developer's representatives. This type of 'economic gain' would definitely not help empower the local community economically, and certainly not help them psychologically and socially.

According to Scheyvens (1999), these are the signs of tourism's psychological and social empowerment of a local community: (1) an enhanced self-esteem because of outside recognition of the uniqueness and value of the community culture, natural resources and traditional knowledge; (2) an enhanced community equilibrium by which the individuals and families work together to build a successful tourism venture. However, the development of NCTZ brought none of these signs. Instead, the following was the reality the researcher had encountered throughout his investigation. The villagers would rather try to gain economic benefits from tourism than develop a realistic understanding of its impacts. The in-depth interviews indicated the majority of the villagers were in favour of developing NCTZ, but this supportive attitude was mainly caused by the fact that expropriating their land would mean a large sum of compensation. Few of the villagers could envision how their lives might change after losing the land, so would not consider investing the compensation money in other businesses to sustain their livelihood. In the meantime, the 'good fortune' of the Duck Pond Village stimulated the jealousy of the people living in the nearby villages whose land was not expropriated. In order to get compensation from the developer, some of them even lodged a complaint against SNIDL with the Provincial People's Congress and People's Political Consultation Conference for not expropriating their land. This could have been a potential move towards the villagers' participation in the development of NCTZ. But the villagers' motive was basically aimed at gaining short-term benefits from tourism rather than determining what they could do to achieve lasting benefits. Throughout this study, the researcher found that sociocultural factors such as the limited capacity of the villagers and their unawareness of tourism impacts had caused their apathy towards participation in tourism. Along with the powerful control of the state over the tourism business and the developer's unwillingness to let the community participate in the development process, they represent a series of problems for China in applying community tourism. Although China is in the midst of 'modernising' its norms and values, it has no civil society to counterbalance the power of the state (Swain, 1990, 1995; Yu et al., 2003; Zhang et al., 1995). It enjoys the benefits of a growing economy, which is generally considered successful, but 
is far from being regulated by the invisible hand of the market (Wen \& Tisdell, 2001; $\mathrm{Xu}, 1999$ ). There is intense social opposition, but there are no social movements that might lead towards building a democratic system (Kuan \& Lau, 2002) crucial to actualising community tourism. Those problems will probably remain unsolved in China for years to come, as the Chinese central Government is still reluctant to institute reform. The political-structural, business-operational and sociocultural barriers therefore will continue to exist. If community tourism were ever to be applied to help achieve the sustainable development of NCTZ, as the researcher had wished, some specific preconditions would have to be established to reduce the barriers.

\section{Conclusion}

Both Western and the Chinese tourism researchers consider community tourism a valuable approach to sustainable development. However, as this brief discussion illustrates, the barriers to applying this democratic approach in a specific Chinese case are tremendous; and some political, economic and sociocultural issues will need to be addressed in order to establish preconditions for actualising community tourism in NCTZ.

The study shows that in NCTZ, the state's reach is powerful and varied in the tourism business. Given the powerful role of the state, appropriate strategies and policies should be the first preconditions to be established for the implementation of community tourism. Instead of the favourable policies adopted by both the national and the local states to developers that focus on attracting more investment, greater efforts should be made to improve coordination mechanisms among the government bodies, the domestic and overseas investors, the tourism planners, and the local populations. NCTZ was planned and developed by SNIDL, consisting of three shareholders: Sanya City Tourism Development Corporation (the Government), Urban International-New York (overseas investor), and Hainan Urban Oil and Chemical Industry Limited (domestic investor). The overseas investor drafted the master plan and the feasibility report. China Buddhist Cultural Institute, China Ethnic Association, China History Museum, Central National University, China Environment Science Institute and the Ecological Research Centre of China Environment Science Institute co-prepared the schematisation. Such a planning process was very fragmented: the nongovernment authorities were concerned with the impetus for development, while the Government was expected to manage the impact of tourism. This may be a missing ingredient in the tourism development process because in this regard the tourism project did not benefit from a full coordination between the local community and the tourism planners (Jenkins, 1982). In addition, laws, rules and regulations governing tourism development should be initiated and developed. China National Tourism Administration (2001b) has already promulgated Regulations on Tourism Planning and Management, but issues regarding community involvement in the tourism development process are still missing in the regulations. An industry code of conduct can direct tourism operations to be more effective and ethical, but initiatives to reduce the traditional government bureaucracy are also essential to create the coordination mechanisms needed for community tourism. In this regard, articles to involve 
communities in the tourism development process should be added to the relevant government laws and regulations to legitimise community participation in the tourism development process in NCTZ, or in China as a whole.

The developer's unwillingness to let the local community be involved in the planning process, and the local residents' apathy and unawareness about participation, are great obstacles to implementing community tourism. Communication and education among the government bodies, the domestic and overseas development authorities, and the local populations are other preconditions to be established for actualising community tourism in NCTZ. Tosun (2000) noted that in some developing countries democratic institutions and regulations were only shared by some state and business elites. This is also true of the NCTZ case in China where a half-century-long communist regime has limited democracy to the state and the business elites (Xia, 1999). The study found that there were government officials with the political strength to manipulate the tourism business as well as the domestic and the overseas developers / investors who had the capital resources to influence the Government. This elite domination was prevalent in the case of NCTZ and the villagers even took it for granted that it would only be a matter between the 'lao ban men' and the state officials to develop NCTZ. While the developer's reluctance to become involved in community participation was due to, among other things, lack of knowledge of the basic principles for community participation, the villagers' apathy and unawareness were mainly caused by their lack of cultural and economic capacity to participate. The future of community tourism in NCTZ clearly hinges on the economic, political, psychological and social empowerment of the local community through the communication of ideas, skills and education among those peoples. Ironically, however, the power and domination of the Chinese central state, and its resistance to the democratic process needed for community tourism, makes it likely to determine the range of future communication and education. A dilemma exists that 'the same centralisation that enables China to make tremendous social and political shifts is highly resistant to its own need for institutional changes' (Zhang et al., 1995: 240), which certainly will not benefit the communication and education crucial to nurturing community participation in the development of NCTZ. Therefore, establishing the above-mentioned preconditions is crucial if community tourism is ever to be applied in NCTZ, or in the whole of China. To help establish the preconditions, the following issues will need to be addressed by similar studies.

Future studies need to address the various impacts of tourism on Chinese local communities. Being a call for increased public participation and a more community-oriented approach to tourism planning in the West (Keogh, 1990), tourism impact studies may also help increase the awareness of tourism practitioners and the general population in China about the value of community participation for sustainable development. Earlier studies of tourism impacts covered local societies in many parts of the world (Bodley, 1990; Boniface \& Fowler, 1993; Cohen, 1996; MacCannell, 1992; Mathieson \& Wall, 1997; Poirier, 1995; Wilson, 1996; Woodley, 1993) but not in contemporary China. A few studies addressed tourism impacts on local communities in China (Oakes, 1995, 1998; Swain, 1989, 1990, 1993, 1995; Toops, 1995; Vincanne, 1996), but only focused on the ethnic minorities in remote regions and reflected the impacts on a small portion of the 
Chinese population. Some previously mentioned Chinese researchers noted tourism's impacts on the majority population, but under the Chinese Government's censorship they could not sufficiently address issues that were socially and politically sensitive in China ( $\mathrm{Li}, 2002)$, such as the causes and the effects of the Chinese Government's policies on culture and religion associated with tourism impacts. It was a limitation in this study that the role of the Buddhist community in Nanshan was not sufficiently investigated for the earlier mentioned reasons. However, the Chinese traditional taste of viewing nature and landscapes is closely associated with the nation's many sacred mountains and rivers where century-long religious sites are still popular tourist attractions (Peterson, 1995). Studies on the role of the religious community in the tourism development of those sites may generate significant theoretical and practical implications for the research of community tourism in China.

The previously mentioned problems of China were manifested in NCTZ as politically structural, business-operational and sociocultural barriers to applying community tourism. To a certain extent they also reflected what Oakes (1998) called paradoxes in China's search for modernity. According to Oakes, China's current modernisation campaign is a paradoxical process through which the people produce, confront, and negotiate a particular kind of socioeconomic change. A 'false modernity' is constructed in the utopian, teleological modernity of 19th- and 20th-century historicism, of the nation-state, and of the institutions of rationalism and scientific objectivity. It is this sense of modernity that the people in the less developed China believe they are pursuing. The industrialised West remains their most significant model for that pursuit. However, modernity itself is paradoxically laden in meaning. The 'authentic modern' denotes that modernity is not constructed in some discernible modern 'essence' but in a process-oriented approach to modernity, one in which human subjectivity is ambivalently but irrevocably engaged in a struggle over the trajectory of socioeconomic change. An essentially 'modern' phenomenon, tourism in China should be illustrated through the paradoxical struggles between the objectifications of 'false modernity' and the promise of the 'authentic' modern subjectivity that is potentially liberating Chinese society. The researcher would suggest that future studies follow Oakes' (1998) paradoxical approach to modernity when researching the complexity of applying community tourism in China. This will help understand the contradictions in contemporary China that generate the problems of applying community tourism, and will also yield policy implications for achieving the four empowerments of the community crucial to sustainable tourism development (Scheyvens, 1999).

While residents in many tourism regions of China are still economically poor, having little capacity to participate in the tourism development process, Chinese tourists are becoming mature, drawn from an ever-increasing middle-class population along with the country's opening to the outside world (Lew \& McKercher, 2002; Zhang \& Lam, 1999). Their perceptions, expectations, attitudes and values, all essential to their decisions in tourist consumption, will influence the developers' strategies and the state's policies. Given China's contemporary growth and change, there will be an increasing number of Chinese tourists on the move domestically and internationally. Future studies may focus on the Chinese tourists' experiences of other cultures and societies on their changing views 
regarding sociocultural, economic, political and environmental issues at home. Their changing views may not change China's dominant political structure currently constraining communities from participating in the tourism development process, but from them we can see a ray of hope. Tourism has enabled the Chinese people to move freely on a global scale. Pampered and admired as the middle class and the newly rich, a growing number of Chinese people, for the first time in Chinese history, have started to consider the individual as being more important than the collective through enjoying such freedom, condemned as bourgeois indulgence by communist dogma (Wong, 1999). With its policy of opening the country to the outside world, the regime itself may have unwittingly sown the seeds of its own destruction.

\section{Acknowledgement}

This research was supported by Hui Oi Chow Trust Fund.

\section{Correspondence}

Any correspondence should be directed to Dr Yiping Li, Department of Geography, The University of Hong Kong, Pokfulam Road, Hong Kong, China (liyiping@hkucc.hku.hk).

\section{References}

Askew, I. (1989) Organizing community participation in family planning projects in South-Asia. Studies in Family Planning 20 (4), 185-202.

Atkinson, A. (1991) Principles of Political Ecology. London: Belhaven.

Bodley, J.H. (1990) Victims of Progress. Mountain View, CA: Mayfield.

Boniface, P. and Fowler, P.J. (1993) Heritage and Tourism in the 'Global Village'. London: Routledge.

Brunt, P. and Courtney, P. (1999) Host perceptions of sociocultural impacts. Annals of Tourism Research 26 (3), 493-515.

Butler, R.W. (1980) The concept of a tourism area cycle of evolution: Implications for the management of resources. Canadian Geographer 24 (1), 5-12.

Cai, X.H., Wang, X.W. and Zeng, Y.M. (2000) Luyou huodong de shehui fujia chengben fenxi [Analyzing the social costs of tourism activities]. Kaifa Yanjiu [Development Studies] 2000 (1), 31.

China National State Council (1981) Zongjiao Huodong Changsuo Guanli Tiaoli [Regulations Regarding Management and Operation of Religious Sites and Temples]. Beijing: China National State Council.

China National Tourism Administration (CNTA) (2001a) Yearbook of China Tourism Statistics. Beijing: CNTA.

China National Tourism Administration (CNTA) (2001b) Regulations on Tourism Planning and Management. Beijing: CNTA.

Cohen, E. (1996) Thai Tourism: Hilltribes, Islands and Tourist-oriented Prostitution. Bangkok: White Lotus.

Doxey, G.V. (1975) A causation theory of visitor-resident irritants. Proceedings of the Sixth Annual Conference on Travel and Tourism Research Association (pp. 195-8). San Diego, USA.

Gormsen, E. (1995). Travel behavior and the impacts of domestic tourism in China. In A.A. Lew and L. Yu (eds) Tourism in China: Geographic, Political, and Economic Perspectives (pp. 131-40). Boulder, CO: Westview.

Hainan Tourism Bureau (1995-2001) Tourism statistics. Unpublished government documents. Haikou, Hainan, China: Hainan Provincial Government.

Hatton, M.J. (1999) Community-Based Tourism in the Asia-Pacific. Toronto: School of Media Studies at Humber College. 
Huang, P.C.C. (1991) The paradigmatic crisis in Chinese studies: Paradoxes in social and economic history. Modern China 17 (3), 299-341.

Inskeep, E. (1991) Tourism Planning: An Integrated and Sustainable Development Approach. New York: Van Nostrand Reinhold.

Jenkins, C.L. (1982) The effects of scale in tourism projects in developing countries. Annals of Tourism Research 9 (2), 229-50.

Keller, C.P. (1987) Stages of peripheral tourism development - Canada's Northwest territories. Tourism Management 8 (1), 20-32.

Keogh, B. (1990) Public participation in community tourism planning. Annals of Tourism Research 17 (3), 449-65.

Kuan, H.C., and Lau, S.K. (2002) Traditional orientations and political participation in three Chinese societies. Journal of Contemporary China 11 (2), 297-318.

Lew, A.A. and McKercher, B. (2002) Trip destinations, gateways and itineraries: The example of Hong Kong. Tourism Management 23 (6), 609-21.

Li, Y. (2002) The impacts of tourism in China on local communities. Asian Studies Review 26 (4), 471-86.

Li, T.Y. and Wang, L.Y. (1988) Luyouxue Gailun [Introduction to Tourism Studies]. Tianjin: Nankai University Press.

Lin, N.Z. and Tao, H.J. (1986) Luyou Jingjixue [Tourism Economics]. Shanghai: People's Press.

Liu, M. (2001) Luyoudi zhoubian xiangcun shequ de gongneng yu jiegou gengxin [Functional and structural renewal of rural communities surrounding tourism destinations]. Huazhong Shifandaxue Xuebao [Academic Journal of Central China Normal University] 35 (1), 95.

Liu, W.H (2000) Guanyu shequ canyu luyou fazhan de ruogan sikao [Reflection on community participation in tourism development]. Luyou Xuekan [Tourism Studies] 15 (1), 47.

Liu, Z.L. (1992) Luyou dui jiedaidi de yingxiang [The impacts of tourism on a destination]. Luyyou Xuekan [Tourism Studies] 7 (3), 52-5.

Liu, Z.P. (1999) Luyou dui zhoubian diqu shehui wenhua yingxiang yanjiu jiegou kuangjia [A framework for studying the social and cultural impacts of tourism on destinations]. Guilin Luyou Gaodengzhuakexuexiao Xuebao [Academic Journal of Guilin Tourism Higher Learning Institute] 10 (1), 29.

MacCannell, D. (1992) Empty Meeting Ground: The Tourist Papers. London: Routledge.

Mathieson, A. and Wall, G. (1997) Tourism: Change, Impacts and Opportunities. Harlow: Longman.

Mitchell, R.E. (2001) Community integration: Island tourism in Peru. Annals of Tourism Research 28 (1), 113-39.

Murphy, P.E. (1985) Tourism: A Community Approach. New York: Methuen.

Oakes, T. (1995) Tourism in Guizhou: The legacy of internal colonialism. In A.A. Lew and L. Yu (eds) Tourism in China: Geographic, Political, and Economic Perspectives (pp. 203-22). Boulder, CO: Westview.

Oakes, T. (1998). Tourism and Modernity in China. London: Routledge.

Pearce, P.L., Moscardo, G. and Ross, G.F. (eds) (1996) Tourism Community Relationship. New York: Pergamon.

People's Republic of China (1998) Law of the People's Republic of China on Land Management. Promulgated 29 August 1998 as order No. 8 of the president of the People's Republic of China. Beijing: National People's Congress

Peterson, Y.Y. (1995) The Chinese landscape as a tourist attraction: Image and reality. In A.A. Lew and L. Yu (eds) Tourism in China: Geographic, Political, and Economic Perspectives (pp. 141-54). Boulder CO: Westview.

Poirier, R.A. (1995) Tourism and development in Tunisia. Annals of Tourism Research 22 (1), 157-71.

Potts, T.D. and Harrill, R. (1998) Enhancing communities for sustainability: A travel ecology approach. Tourism Analysis 3 (1), 133-42.

Ryan, C. and Montgomery, D. (1994) The attitudes of Bakewell residents to tourism and issues in community responsive tourism. Tourism Management 15 (5), 358-69. 
Sanya Nanshan Industry and Development (1998-2001) Feasible report of Sanya Nanshan Cultural Tourism Zone. Unpublished company documents. Sanya, Hainan, China: Sanya Nanshan Development.

Sanya Nanshan Industry and Development (2003) Sanya Nanshan Cultural Tourism Zone. On WWW at http: / / www.nanshan.com.

Sanya Tourism Bureau (1998-2001) Tourism statistics. Unpublished government documents. Sanya, Hainan, China: Sanya City Government.

Scheyvens, R. (1999) Case study: Ecotourism and the empowerment of local communities. Tourism Management 20 (2), 245-9.

Simmons, D.G. (1994) Community participation in tourism planning. Tourism Management 15 (2), 98-108.

Smith, V.L. (1989) Eskimo tourism: Micromodels and marginal men. In V.L. Smith (ed.) Hosts and Guests: The Anthropology of Tourism (pp. 55-82). Philadelphia: University of Philadelphia Press.

Stone, L. (1989) Cultural cross-roads of community participation in development: A case from Nepal. Human Organization 48 (3), 206-13.

Stonich, S.C. (1998) Political ecology of tourism. Annals of Tourism Research 25 (1), $25-54$.

Swain, M.B. (1989) Developing ethnic tourism in Yunnan, China: Shilin Sani. Tourism Recreation Research 14 (1), 33-9.

Swain, M.B. (1990) Commoditizing ethnicity in Southwest China. Cultural Survival Quarterly 14 (1), 26-9.

Swain, M.B. (1993) Women producers of ethnic arts. Annals of Tourism Research 20 (1), 32-51.

Swain, M.B. (1995) A comparison of state and private artisan production for tourism in Yunnan. In A.A. Lew and L. Yu (eds) Tourism in China: Geographic, Political, and Economic Perspectives (pp. 223-33). Boulder, CO: Westview.

Tang, T.S. (1998) Luyou mudidi de shequhua ji shequ luyou yanjiu [Community development of destination and study of community tourism]. Dili Yanjiu [Geographic Study] 17 (2), 145.

Til, V.J. (1984) Citizen participation in the future. Policy Studies Review 3 (2), 311-22.

Timothy, D.J. (1999) Participatory planning: A view of tourism in Indonesia. Annals of Tourism Research 26 (2), 371-91.

Toops, S. (1995) Tourism in Xinjiang: Practice and place. In A.A. Lew and L. Yu (eds) Tourism in China: Geographic, Political, and Economic Perspectives (pp. 179-202). Boulder, CO: Westview.

Tosun, C. (2000) Limits to community participation in the tourism development process in developing countries. Tourism Management 21 (6), 613-33.

Urban International-New York. (1997) Sanya Nanshan Cultural Tourism Zone master plan. Unpublished document of Sanya Nanshan Cultural Tourism Zone.

Vincanne, A. (1996) Karaoke as modern Lhasa, Tibet: Western encounters with cultural politics. Cultural Anthropology 11 (3), 510-46.

Wen, J.J. and Tisdell, C.A. (2001) Tourism and China's Development: Policies, Regional Economic Growth and Ecotourism. Singapore: World Scientific.

Williams, P.W. and Gill, A. (1994) Tourism carrying capacity management issues. In W.F. Theobald (ed.) Global Tourism (pp. 174-87). Oxford: Butterworth-Heinemann.

Wilson, D. (1996) Paradoxes of tourism in Goa. Annals of Tourism Research 24 (1), 52-75.

Wong, J. (1999) Jan Wong's China: Report from a Not-so-foreign Correspondent. Toronto: Doubleday.

Woodley, A. (1993) Tourism and sustainable development: The community perspective. In J.G. Nelson, R. Butler, and G. Wall (eds) Tourism and Sustainable Development: Monitoring, Planning, Managing (pp. 135-46). Waterloo: Heritage Resources Centre, University of Waterloo.

World Travel and Tourism Council, World Tourism Organization, and Earth Council (1995) Agenda 21 for the Travel and Tourism Industry: Towards Environmentally Sustainable Development. London: World Travel and Tourism Council. 
Wu, R.W. (2000) Luyou guihua de fazhan lichen yu qushi [Evolution and trend of tourism planning]. Nongcun Shengtai Huanjing [Ecological Environment of the Countryside], 16 (1), 38.

Xia, D.M. (2001) Congfen fahui zongjiao ziyuan youshi, genghao di fuwu yu renleishehui [Make full use of religious resources to serve the human society]. Shijie Zongjiao Wenhua [Culture of World Religions] 3, 26-27.

Xia, M. (1999) From camaraderie to the cash nexus: Economic reforms, social stratification and their political consequences in China. Journal of Contemporary China 8 (21), 345-58.

Xu, G. (1999). Tourism and Local Economic Development in China: Case Studies of Guilin, Suzhou and Beidaihe. Surrey: Curzon.

Yu, L., Ap, J. Zhang, G., and Lew, A.A. (2003) World trade and China's tourism: Opportunities, challenges, and strategies. In A.A. Lew, L. Yu, J. Ap and G. Zhang (eds) Tourism in China (pp. 297-309). New York: Haworth Hospitality.

Zhang, G.R. (1995) China's tourism development since 1978: Policies, experiences, and lessons learned. In A.A. Lew and L. Yu (eds) Tourism in China: Geographic, Political, and Economic Perspectives (pp. 3-18). Boulder, CO: Westview.

Zhang, G.R. (1998) Guanyu luyouye de ershiyi shiji yicheng - Shixian yu huanjing xiang shiyin de kechixu fazhen [Agenda 21 for the travel and tourism industry: Towards environmentally sustainable development]. Luyou Xuekan [Tourism Studies] 13 (2-5).

Zhang, G.R., Yu, L. and Lew, A.A. (1995) China's tourism: Opportunities, challenges, and strategies. In A.A. Lew and L. Yu (eds) Tourism in China: Geographic, Political, and Economic Perspectives (pp. 237-44). Boulder, CO: Westview.

Zhang, Q.H. and Lam, T. (1999) An analysis of mainland Chinese visitors' motivations to Hong Kong. Tourism Management 20 (5), 587-97.

Zhang, Y. (ed.) (1957) Zhongguo Jindai Nongyeshi Ziliao [Source Materials on the Agricultural History of Modern China]. Beijing: Sanlian Shudian 
Copyright of Journal of Sustainable Tourism is the property of Multilingual Matters and its content may not be copied or emailed to multiple sites or posted to a listserv without the copyright holder's express written permission. However, users may print, download, or email articles for individual use. 